\title{
Erratum to: Polysubstituted Phenyl Glucosides Produced by the Fungus Metarrhizium anisopliae
}

Wen-jing WANG, Chong DAI, Jian-ping WANG, Hu-cheng ZHU, Chun-mei CHEN, Yong-hui ZHANG

Hubei Key Laboratory of Natural Medicinal Chemistry and Resource Evaluation, Tongji Medical College, Huazhong University of Science and Technology, Wuhan 430030, China

(C) Wen-jing WANG, Chong DAI, Jian-ping WANG, Hu-cheng ZHU, Chun-mei CHEN, Yong-hui ZHANG 2020

\author{
Current Medical Science \\ DOI https://doi.org/10.1007/s11596-020-2168-2 \\ 40(2):232-238,2020
}

\begin{abstract}
The article "Polysubstituted Phenyl Glucosides Produced by the Fungus Metarrhizium anisopliae", written by Wen-jing WANG, Chong DAI, Jian-ping WANG, Hu-cheng ZHU, Chun-mei CHEN, Yong-hui ZHANG, was originally published electronically on the publisher's internet portal on May 2020 without open access. With the author(s)' decision to opt for Open Choice, the copyright of the article is changed to (C) The Author(s) 2020 and the article is forthwith distributed under a Creative Commons Attribution 4.0 International License (https://creativecommons.org/licenses/by/4.0/), which permits use, sharing, adaptation, distribution and reproduction in any medium or format, as long as you give appropriate credit to the original author(s) and the source, provide a link to the Creative Commons license, and indicate if changes were made..
\end{abstract}

The original article has been corrected.

Corresponding authors: Chun-mei CHEN, Yong-hui ZHANG 